\title{
Spatial Distribution, Behaviour, and Biological Aspect of Albacore (Thunnus alalunga) Caught in Eastern Indian Ocean
}

\author{
Fathur Rochman*, Irwan Jatmiko and Bram Setyadji \\ Research Institute for Tuna Fisheries, Bali, Indonesia \\ Jl. Mertasari no. 140 Br. Suwung Kangin DS. Sidakarya, Denpasar-Bali, Indonesia 80224 \\ Email: fathursmasabio1@gmail.com
}

\begin{abstract}
This study highlighted the occurrence of the Indonesian tuna longline fishery targeting albacore (Thunnus alalunga) caught in the Eastern Indian ocean. The data used in this study based on the Research Institute for Tuna Fisheries (RITF) observer program in Benoa. This paper presents the current information on biological aspect (size distribution and length-weight relationship) and fish behavior (swimming layer and feeding periodicity) of albacore. Total albacore samples of 3,152 were taken from scientific observer data from 20102013. The study area of albacore was between 0-33 ${ }^{\circ} \mathrm{S}$ and $75-131^{\circ} \mathrm{E}$. Albacore length distributed from $70-196$ cmFL (median=93 cmFL, mode=100 cmFL, mean=92.12 cmFL) and dominated at size of $95 \mathrm{cmFL}$. The highest percentage length of albacore was $>90 \mathrm{~cm}$ (L50) occured in the area between ( $30-35^{\circ} \mathrm{S}$ and $\left.80-95^{\circ} \mathrm{E}\right)$ and (10-15 ${ }^{\circ} \mathrm{S}$ and $120-125^{\circ} \mathrm{E}$ ). The length weight relationship was determined to be $\mathrm{W}=0.0045 \mathrm{FL} 1.8211$ (W in $\mathrm{kg}, \mathrm{FL}$ in $\mathrm{cm}$ ). The expected season to catch the ALB was from April to July with the peak season in June and July. The swimming layer of albacore based on minilogger data were distributed from at 118 to $341 \mathrm{~m}$ depth and mostly catch at depth of $156 \mathrm{~m}$ with temperature degree $18^{\circ} \mathrm{C}$. The feeding periodicity of albacore's are start from 7:45am to 17:59 pm, mostly active at $10 \mathrm{am}$ to $11 \mathrm{am}$. The majority of ALB caught by Indonesian longliner was mature condition and negative allometric growth. The ALB peak season was in June-July and the best time to catch was $10 \mathrm{am}$ to $11 \mathrm{am}$ at depth of $156 \mathrm{~m}$.
\end{abstract}

Keywords : albacore, feeding periodicity, swimming layer, CPUE

\section{Introduction}

Albacore (ALB) is one of a major important commercial species of Indonesian tuna longline fisheries in Eastern Indian Ocean. The production of albacore (Thunnus alalunga) was the third-largest tuna after yellow fin tuna ( $T$. albacares) and big eye tuna ( $T$. obesus). Groups of tuna production reached up to $1,297,062$ tons from 2004-2011. The total catch production consist of yellow fin tuna $69 \%$, big eye tuna $24 \%$, albacore $6 \%$ and southern blue fin tuna $1 \%$. Most of which were exported to Japan (DGCF, 2012)

Albacore ( $T$. alalunga) is a temperate tuna species, widely distributed in temperate and tropical waters of all oceans. The main fisheries are in temperate waters. In the Atlantic, their geographic limits are from $45-50^{\circ} \mathrm{N}$ and $30-40^{\circ} \mathrm{S}$, while in the Indian Ocean, their distribution ranges from $50 \mathrm{~N}$ to $40^{\circ} \mathrm{S}$ with adults occurring from $5^{\circ} \mathrm{N}$ to $25^{\circ} \mathrm{S}$ (ISSF, 2014).

In the Indian Ocean, albacore is caught almost exclusively under drifting longline (98\%), with remaining catches recorded under purse seines and other gears (IOTC, 2007; Nishida and Tanaka, 2008). Catch of ALB by Indonesian longline fleets operating in Indian Ocean from 2004-2006 was estimated at 9,081 tons by IOTC, while $53.4 \%$ of which was landed at Benoa fishing port (Proctor et al., 2007).

The information about distribution and environment factor is important to determine CPUE and stock assessment, especially for migratory species (Lehodey, 2001). (Rochman et al., 2016) shows that environmental factor such as temperature, salinity, dissolve oxygen, and nutrition were greatly influenced ALB behaviour both in vertical and horizontal movement. Furthermore, (Rochman et al., 2016) indicated that ALB tend to stay at thermocline zone with at depths of 118-291 m with temperature ranged from $12.41-20.47^{\circ} \mathrm{C}$, dissolve oxygen from $3.24-4.68 \mathrm{ml}^{-\mathrm{L}^{-1}}$ and the average salinity at $34.90 \mathrm{psu}$. The aims of this research is to recognize the current information on spatial distribution, effort, behaviour and biological aspect of albacore ( $T$. alalunga) in Eastern Indian Ocean based by scientific observer program. 


\section{Materials and Methods}

Data of ALB were obtained from on board observer program on commercial tuna longline fleets based at Benoa-Bali in period of March 2010-October 2013. Based on 25 fishing trips (2.338 fishing days), catch and effort data were collected. Data collected using fork length (cmFL) with level of accuracy $1 \mathrm{~cm}$ and setting recorded by global positioning system (GPS). The fishing effort (f) and CPUEs for ALB are used as additional information and calculated using the following formula, modified from De Metrio and Megalofonou (1998).

Where a' is the average number of hooks in longline per day (divided by the 1,000 hooks longline effort unit), d' is the number of fishing days per trip.

CPUE $=N / f$ ( $N$ is the number of fish caught) $C P U E=B / f$ ( $B$ is the biomass of fish caught)

Length (L) -weight (W) relationship of ALB was fitted to 269 speciments using fork length (cmFL). The parameter $(a, b)$ of the power equation describing the length-weight relationship :

$$
W=a L^{b}
$$

Where $a$ and $b$ are constanta of the equation value.

Distribution of seasonal mean of length and seasonal mean of weight tested by One way ANOVA and followed by Post Hock Test (Scheffe Test) to recognized least significant different among month. In this study, minilogger was used to determine the depth of hook and hook timers to recognize the feeding periodicity. The type of hook timer was HT
600 from NKE Instrumentation. The hook timers were fitted into the one series with branch line and will be linked directly with main line. The type of minilogger was SP2T-1200 from NKE Instrumentation. Minilogger was fitted at the end of branch line and replaced the hook. (Figure 1) shows the position of minilogger and hook timer on tuna longline gear. Radio data pencil is used to transfer data from minilogger to WinMemo program in the computer. The feeding periodicity data which was obtained from hook timer then analyzed using the diagram.

\section{Study area}

The study area of ALB can be described base on result of onboard observer program in 20102013. The ALB fishing area caught by tuna longline fisheries was between $0-33^{\circ} \mathrm{S}$ and $75-131^{\circ} \mathrm{E}$. The ALB fishing area mostly conducted outside Indonesian Exclusive Economic Zone (EEZ) (Figure 2). The catch data including CPUEs, and size of ALB were georeferenced in $5^{\circ}$ grids of latitude and longitude. Surfer 9 program is used to describe spatial distribution of CPUE and size.

\section{Results and Discussion}

\section{Size distribution}

Total of 3152 ALB samples were taken from scientific observer data ranged from 2010-2013. ALB length (cmFL) distributed from 70-196cmFL (median=93 $\mathrm{cmFL}$, mode $=95 \mathrm{cmFL}$, mean=92.12 $\mathrm{cmFL}$ ) and dominated at size $95 \mathrm{cmFL}$ (Figure 3 and Figure 4.).

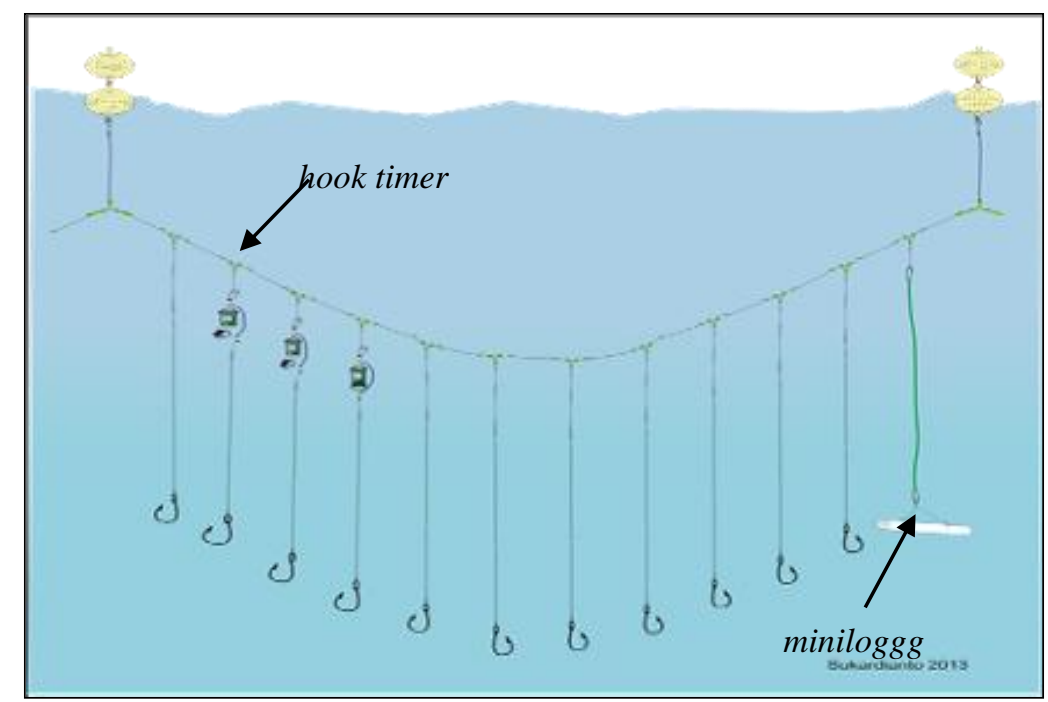

Figure 1. The position of hook timer and minilogger on tuna longline gear 


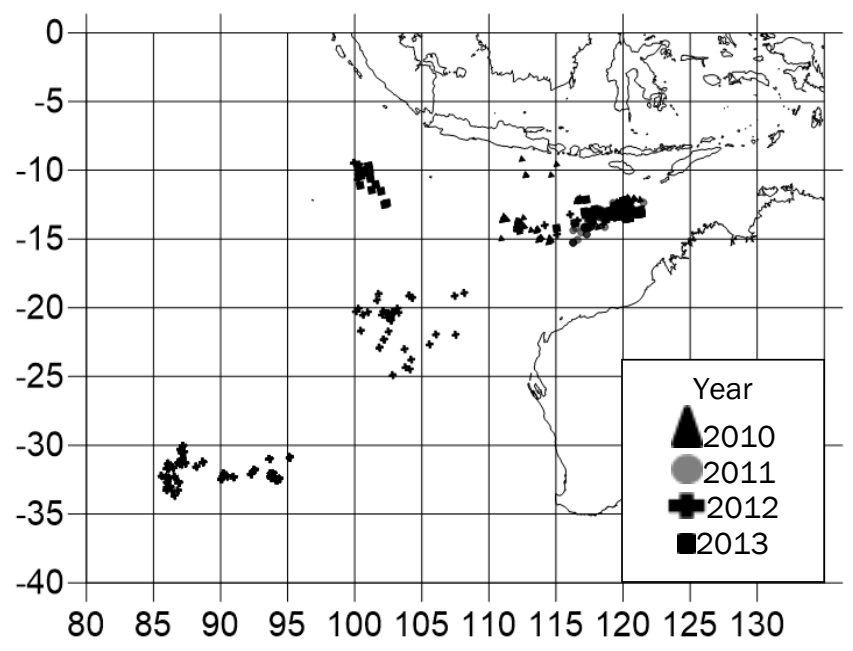

Figure 2. Map of the study area of ALB in Eastern Indian Ocean by Indonesian Tuna Longline fleets sets from 2010-2013.

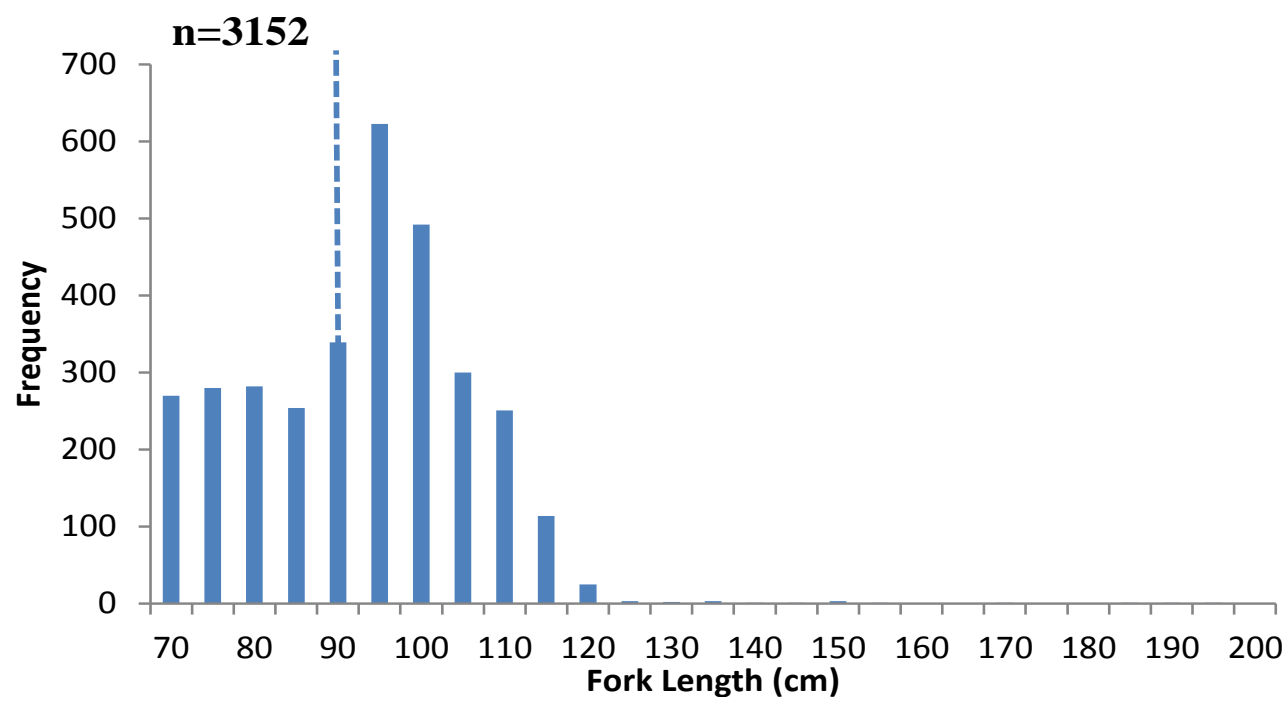

Figure 3. Length frequency distribution for ALB observed taken in Indonesian longline fishery operating in Eastern Indian Ocean in 2010-2013.

The highest percentage length of ALB $>90 \mathrm{~cm}$ (L50) occured in the area between (30-350S and 80$\left.95^{\circ} \mathrm{E}\right)$ and $\left(10-15^{\circ} \mathrm{S}\right.$ and $\left.120-125^{\circ} \mathrm{E}\right)$ (Figure 5.). This $112 \mathrm{cmFL}$ ). Farley et al. (2012) reported that in South West Pacific Ocean (fish ranged from 43-115cmFL and dominated at size $90-95 \mathrm{cmFL}$ ). According to Ueyanagi (1969) and Wu and Kuo (1993), the length at the first maturity of Indian Ocean Albacore was 90 cmFL.

Seasonal mean-length distribution was significantly different among month (ANOVA test). According to the Scheffe post hock test, the largest difference occurred in June (mean=97.96 cmFL) and August (mean=79.74 cmFL) (scheffe test, $P<0.001$ ). study observed similar research to that of Eastern Indian Ocean reported by Setyadji et al. (2012) (fish ranged from 36-126 cmFL and dominated at size 93The highest mean-length distribution occurred in June and the lowest occurred in August. This might be due to seasonal movement caused by sea surface temperature (SST) that influenced reproductive behavior (Chen et al., 2005).

Mature ALB (Lm>90 cmFL) were mainly distributed in Eastern Indian Ocean south of 10$35^{\circ} \mathrm{S}$ and $80-135^{\circ} \mathrm{E}$ and showed widely distributed pattern. The highest concentration of mature ALB conducted at $\left(30-35^{\circ} \mathrm{S}\right.$ and $\left.80-95^{\circ} \mathrm{E}\right)$ and $\left(10-15^{\circ} \mathrm{S}\right.$ and $120-125^{\circ} \mathrm{E}$ ) (Figure 5.). Chen at al. (2005) 
reported that mature albacore concentrated in the Indian Ocean south of $10^{\circ} \mathrm{S}$ but showed a widely distributed pattern. In north of $10^{\circ} \mathrm{S}$, mature albacore (about $22 \mathrm{~kg}$ ) occurred all year. In the region between $10^{\circ} \mathrm{S}$ and $30^{\circ} \mathrm{S}$, the albacore were mostly mature. The significant difference $(P<0.001)$ in weight composition occurred between the spawning and non-spawning periods. More immature albacore occur in region between $10^{\circ} \mathrm{S}$ and $30^{\circ} \mathrm{S}$ during the non-spawning season. Many albacore in region south of $30^{\circ} \mathrm{S}$, are immature, with a mean weight of nearly $13 \mathrm{~kg}$ throughout the year.

\section{Length and weight relationship}

The data were taken from observer program involved 269 samples. The result of $t$-test showed the significant different with $b$ value1.8211 $(<3)$ and $a$ value 0.0045 (Figure 6.). It is assumed that the growth pattern of ALB was negative allometric, where the growth in length is faster than the growth in weight.

The growth in length is faster than the growth in weight. Test of $b$ (slope) value was 1.8211 . According to Zhu et al. (2008) the value of the parameter $b$ was well within the normal range of 2.5 to 3.5. The value of $b<2.5$ or $>3.5$ are often derived from sample with narrow size range. So narrow size range (72-123 cmFL) and limited samples (269) may be contributed to the reason why $b$ value $=1.8211$ $(<2.5)$ was low for ALB in Eastern Indian Ocean. The comparison of length-weight of ALB in another ocean is shown in Table 1 .

Length-weight relationship is an important input to the regional stock assessment as it is used to convert catches in weight into catch in number (Farley et al., 2012). It can also provide information on relative condition of fish (Farley et al., 2012).

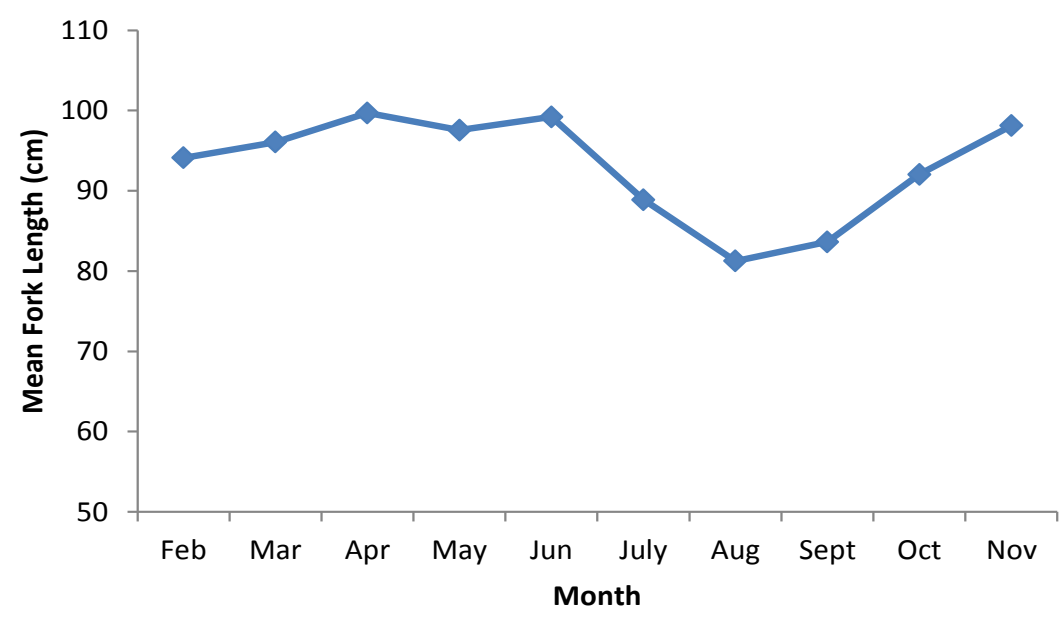

Figure 4. Mean FL distribution by month for ALB observed taken in the Indonesian pelagic longline fishery operating in Eastern Indian Ocean (2010-2013).

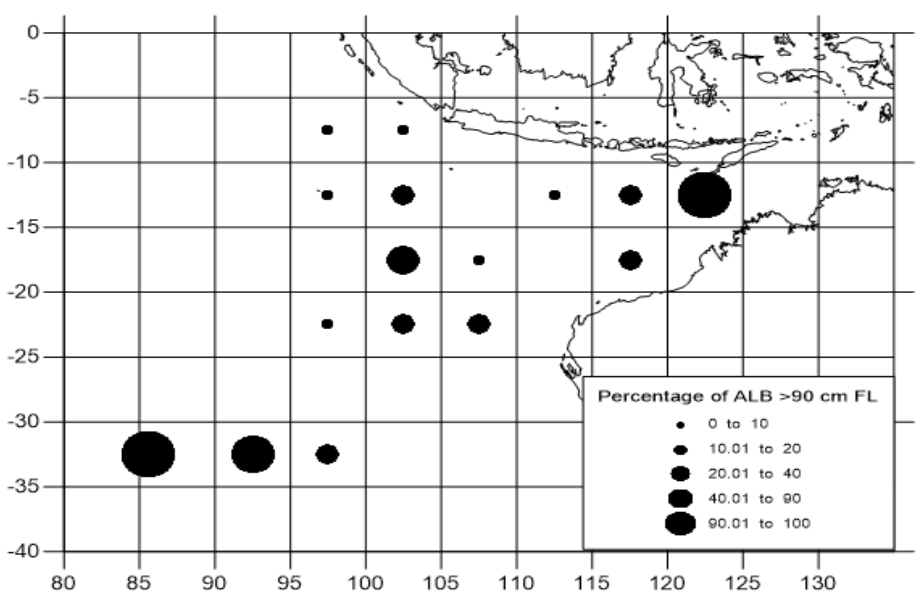

Figure 5. Spatial distribution of percentage of ALB over $90 \mathrm{cmFL}$ recorded by Benoa Observer, aggregated from 2010 to 2013 with $5 \times 5$ grid. 


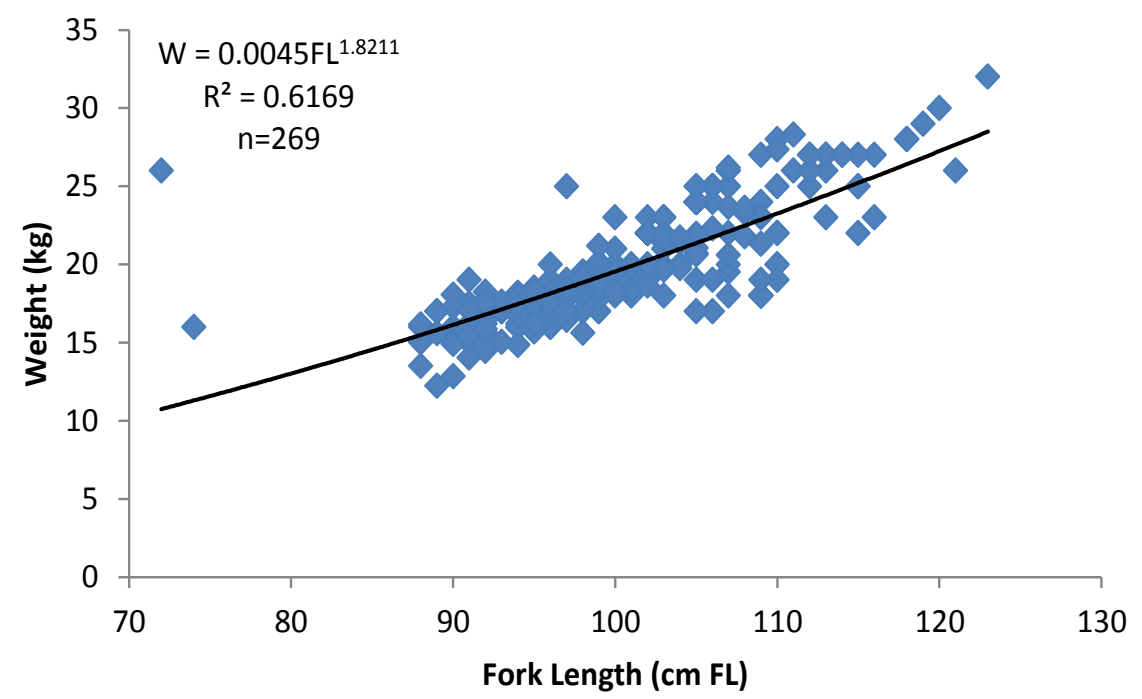

Figure 6. Weight-fork length fit exsponensial model of ALB from the Indonesia's Scientific Observer, operating in Eastern Indian Ocean in 2010-2013

Table 1. Length and weight relationship of ALB in Indian Ocean (compile from several authors)

\begin{tabular}{rlllrrrr}
\hline No & \multicolumn{1}{c}{ Author } & \multicolumn{1}{c}{ Area } & FL Range $(\mathrm{cm})$ & \multicolumn{1}{c}{$\mathrm{n}$} & Intercept $(\mathrm{a})$ & Slope $(\mathrm{b})$ & $\mathrm{R}^{2}$ \\
\hline 1 & This study & Eastern Indian Ocean & $72-123$ & 269 & 0.0045 & 1.8211 & 0.6169 \\
2 & Setyadji et al., ${ }^{23}$ & Eastern Indian Ocean & $83-106$ & 497 & 0.00008 & 2.7271 & 0.6365 \\
3 & Zhu et al., 24 & Indian Ocean & $93-119$ & 88 & 0.00043 & 2.3428 & 0.7644 \\
4 & Hsu et al., 25 & Indian Ocean & $46-112$ & 2499 & 0.05691 & 2.7514 & 0.919 \\
5 & Zhu et al., 26 & Atlantic & $99.1-125$ & 94 & 0.0438 & 2.825 & 0.7628 \\
6 & Zhu et al., 27 & Eastern Pacific & $70.01-118$ & 147 & 0.0542 & 2.76 & 0.8256 \\
\hline
\end{tabular}

The current study indicated that ALB caught in this study area are in relatively poor condition (compare to the previous study in Table 1). ALB samples in the current study were heavier on average for length compare to the previous study (slope $b=1.8211$ ). In addition, morphometrics may not be the best indicator of fish condition and measuring fat content may be better proxy in future studies (Farley et al., 2012).

\section{Swimming layer}

Majority of Indonesian longline fleet based at Benoa port Bali are using middle longline type with 12 hooks and depth between 100-350 m. We used minilogger to recognize the depth of hook. We are assumed that the depth of hook number 1 as equal as number 12 and the depth of hook number 2 as equal as number 11 and so on. The recorded of minilogger data showed that the average of deepest hook type was $341.52 \mathrm{~m}$ depth and the average of shallowest hook type was $117.83 \mathrm{~m}$ depth (Barata et al., 2011a). The recorded data from minilogger showed that the deepest hook was $340 \mathrm{~m}$ and the shallowest hook was $117 \mathrm{~m}$ and the majority of ALB were caught at a depth of $156 \mathrm{~m}$ with fishing pole position no. 2 and 11 (Figure 9).

The data showed that ALB were caught at temperature range from $14-22^{\circ} \mathrm{C}$ and caught more at $18^{\circ} \mathrm{C}$ and a depth of $156 \mathrm{~m}$. Swimming layer is one of the important factor to obtain maximum catches, especially on tuna longline effort. The research showed that ALB majority were taken at a depth of $156 \mathrm{~m}$ with fishing no.2 and 11 (Figure 9.). Nugraha and Triharyuni (2009) mentioned that ALB in Indian Ocean were caught in depth of 150-199.9 m. Chavance (2005), stated that ALB on the West Coast of New Caledonia were caught at a depth of 100-410 $\mathrm{m}$. The depth of hook determined by the length of bouy line, branch line, main line, number of hooks and curvature coefficient among branch. This condition caused the difference of depth measurement (swimming layer) of ALB.

The swimming layer of ALB mostly located in the surface layer to mid layer, but there were some of ALB spreaded into deep layer. The big fish of ALB were in deep layer with a fewer in number, while the smaller ALB were in surface layer with a large number 
of fish. Barata et al. (2011a) reported that ALB dominated $64 \%$ with size $>100 \mathrm{cmFL}$ at depth from 85 to $124.74 \mathrm{~m}$. Chen et al. (2005), showed that the distribution of immature ALB were caught at surface layer, while mature ALB were caught at mid layer. Tuna longliner which is operated based in Benoa, and are divided into 3 types. There are surface longline, mid longline and deep longline (Barata et al., 2011a). According to Irianto et al. (2013), the surface longline type consist of 5 hooks among buoy which was operated at depth of 100 to $175 \mathrm{~m}$, the mid longline type consist of 12 hooks among buoy which was operated at depth of 125 to $350 \mathrm{~m}$, and the deep longline type consist of 18 hooks among buoy which was operated at depth of 150 to $450 \mathrm{~m}$. According to various study above, we can concluded that the assimilation of surface longline type and mid longline type was the suitable way to catch ALB in their habitat.

\section{Feeding periodicity}

The feeding periodicity depends on the distribution of food and the environmental condition. The water pollution can caused the change of feeding periodicity (Effendie, 2002). The intensity of ALB to search of food was in the morning until evening and 1 time periodically in 24 hours. This indicated that ALB was included in diurnal fish.

Based on the onboard observation using hook timer, the intensity of the feeding habit of ALB conducted between $07.45 \mathrm{am}-17.59 \mathrm{pm}$ with the highest frequency at 10.00-11.00am. The average of feeding periodicity at 11.44am (Figure 10.). The activities of diurnal fish have fast movement, active, and migrate within a large area (Effendie, 2002). Gunarso (1998), stated that ALB search for food during the day, while at night quite active to hunt preys.

Musyl et al. (2003) stated that the amount of colour pigment in ALB vision will be influenced to feed habit. The limitation of colour pigment caused that the feeding habit only consentrated in clear water. The ability of sunlight to penetrate the water layer also influenced the ability of fish vision to search of food. In the musky water or in the lower intensity of sunlight, the ability of fish vision to the object in water could be reduced.

Generally, all types of tuna can adjust both the ability of the senses of sight during the day and evening, depending on the setting of cone and rod cells function contained in the fish retina (Masuma et al., 2001). The types of fish which were active during the day, generally have cone that arranged in a rectangular shape. This kind of fish use their visión intensively and active to hunt preys. Tuna fishes were not selective to search for preferred food (Barata et al., 2011b).

\section{Catch number and Catch Per Unit of Effort (CPUE)}

The data of catch number and catch per unit of effort (CPUEs) of ALB caught by tuna longline fleets tabulated by year in (Table 2). ALB CPUEs ranged between 0.688-1.953 fish/1000 hooks. CPUEs for ALB were highest in 2012 and 2013 (1.272 and 1.953 fish. 1000 hooks $^{-1}$ ). The overall moving average of CPUE showed that ALB catches generally increase from November to (June and July) and decrease in August to November (Figure 7). The highest catch of ALB was observed in the area between (30-350S and $\left.80-100^{\circ} \mathrm{E}\right),\left(5-10^{\circ} \mathrm{S}\right.$ and $\left.95-100^{\circ} \mathrm{E}\right)$, and (10-15'S and $120-125^{\circ} \mathrm{E}$ ) (Figure 8).

The CPUEs (no Fish/1,000 hooks) distribution of ALB indicated uneven distribution. The lowest CPUE occurred in 2010 (0.688) and then followed by 2011 (0.694), 2012 (1.272) and 2013 (1.953) (Table 2). The different of CPUE was caused by the different of fishing area (study area). In 2010 and 2011 fishing activities carried out in the near shore of Indonesia territory (10-150S and 110-125'E). In 2012, fishing activities carried out in the west of Australian territory $\left(15-35^{\circ} \mathrm{S}\right.$ and $\left.85-110^{\circ} \mathrm{E}\right)$ and in 2013 fishing activities carried out in the south of Sumatera and west of Java (10-150S and 100$\left.105^{\circ} \mathrm{E}\right)$. According to Levesque (2010), the CPUE value was caused by several factors such as reproductive behavior and feeding behavior. In the open-ocean environment, the availability of food is often limited to specific areas of oceanic convergence

Table 2. Effort, hook rate, catch and CPUEs of ALB caught by Indonesian tuna longline fleets during year 2010-2013.

\begin{tabular}{ccccccccccc}
\hline No & Year & $\sum$ Effort & $\begin{array}{c}\text { Number } \\
\text { of Hooks }\end{array}$ & $\begin{array}{c}\text { Cacth } \\
\text { Number }\end{array}$ & $\begin{array}{c}\text { Tonnage } \\
(\mathrm{kg})\end{array}$ & $\begin{array}{c}\text { Average Weight } \\
(\mathrm{kg})\end{array}$ & (No.fish/1000 hooks) & (number/effort) & (kg/effort) \\
\hline 1 & 2010 & 664 & 841576 & 579 & 12141.48 & 20.96974093 & 0.688 & 0.872 & 18.285 \\
2 & 2011 & 504 & 513216 & 356 & 6857.65 & 19.2630618 & 0.694 & 0.706 & 13.606 \\
3 & 2012 & 792 & 1152852 & 1466 & 21624 & 14.75034106 & 1.272 & 1.851 & 27.303 \\
4 & 2013 & 378 & 384490 & 751 & 13854 & 18.44740346 & 1.953 & 1.987 & 36.651 \\
\hline
\end{tabular}


(currents, and sea mounts or ridge), which creates productive fishing conditions at certain times of year.

The overall moving average of CPUEs (kg.effort-1 or number.effort ${ }^{-1}$ ) showed that ALB catches increased in (June and July) and decreased in August to November (Figure 7). It is in accordance with Lee et al. (1999) which was stated that monthly CPUEs distribution of ALB during October-November are lower than the others month. This is also consistent with research conducted by Research Institute for Tuna Fisheries about Indices of Fishing Season (IFS) of ALB with the case study in Cilacap fishing port, Central Java. The study, mentioned that the tuna fishing season expected to be about 4 months (AprilJuly) with the peak season in May (RITF, 2013).
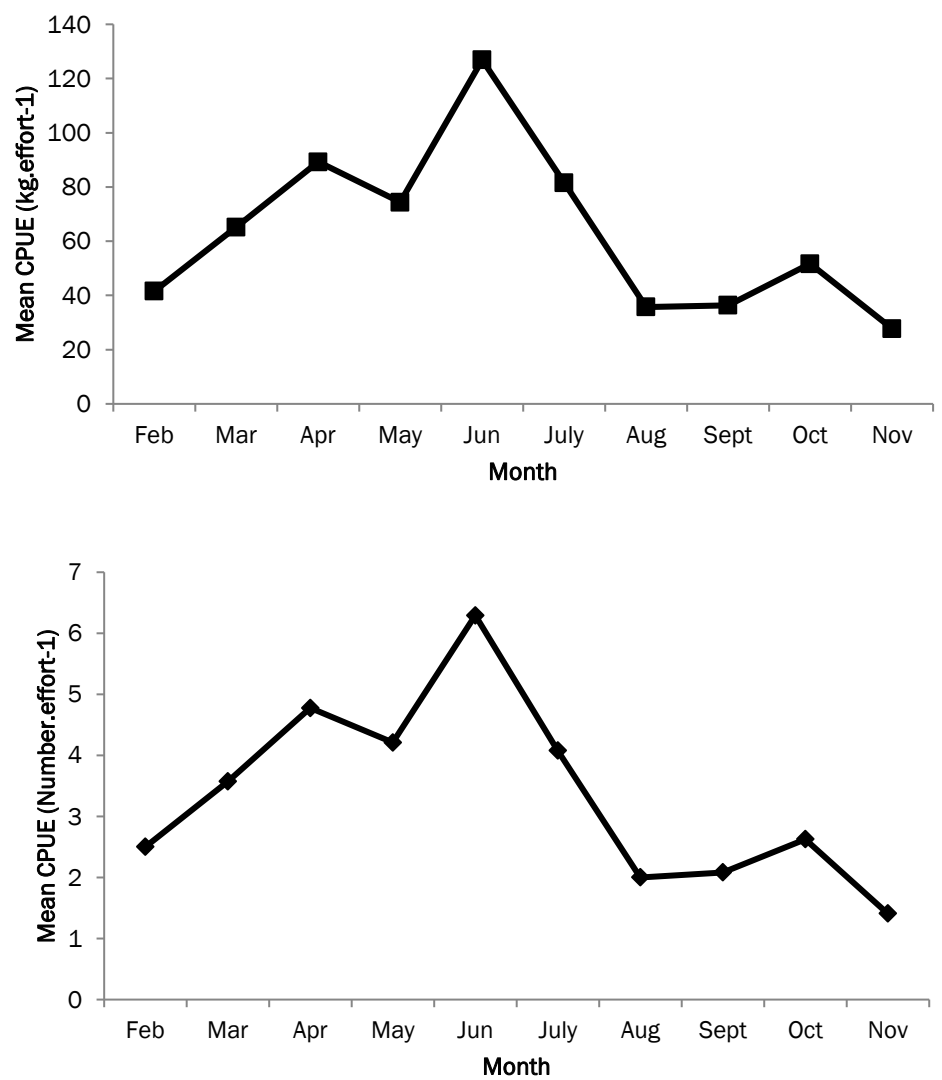

Figure 7. Nominal CPUEs by month for ALB recorded by observer during year 2010-2013

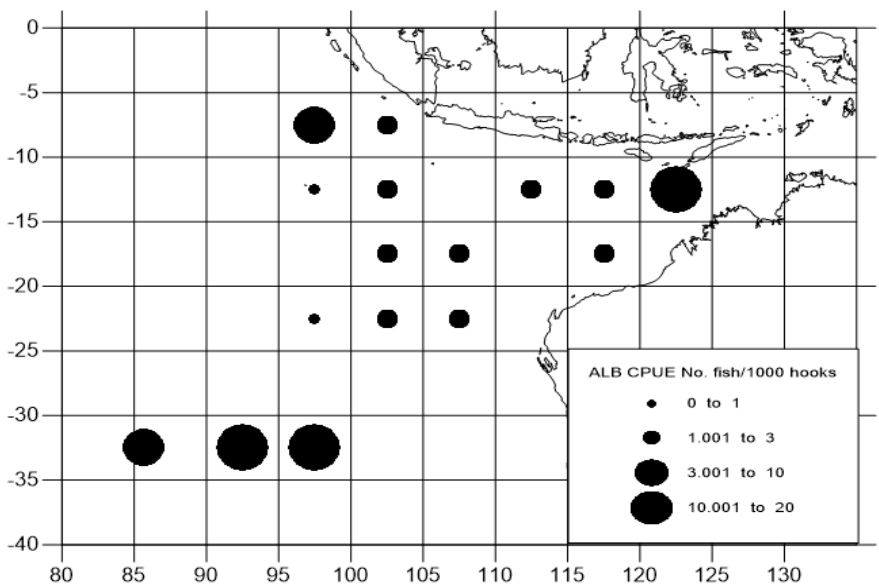

Figure 8. Spatial distribution of nominal CPUEs (no. fish/1000 hooks) for ALB recorded by Benoa Observer, aggregated from 2010 to 2013 with $5 \times 5$ grid. 


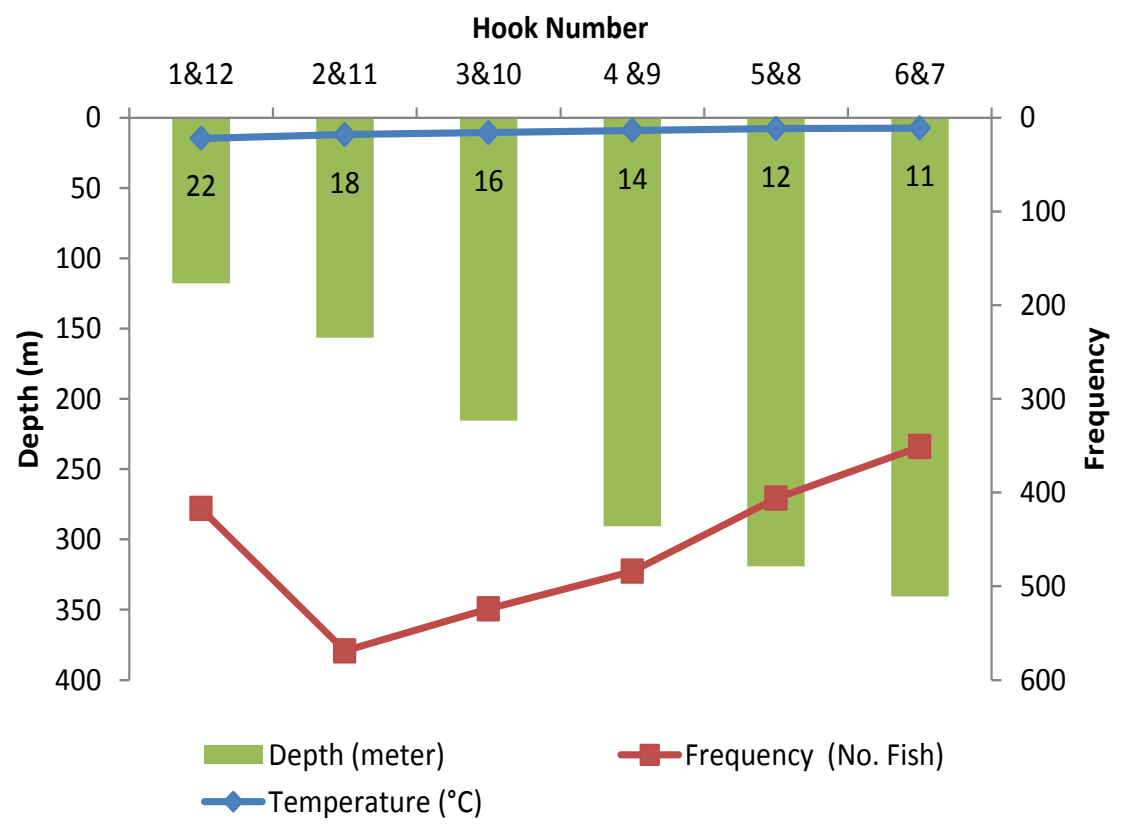

Figure 9. The relationship between the number of hooks, depth, temperature and frequency of ALB caught by Indonesian longline fleets in Eastern Indian Ocean

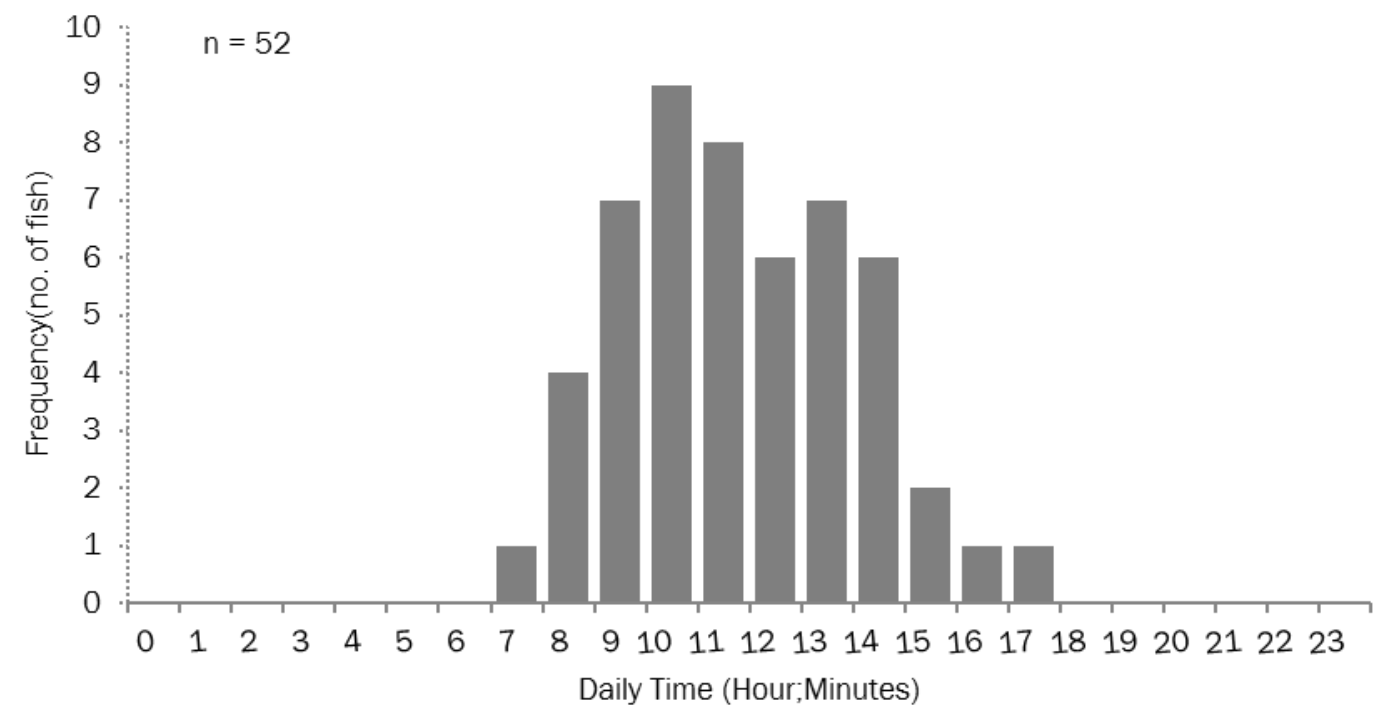

Figure 10. The feeding periodicity of ALB based on data obtained from hook timer

\section{Conclusion}

The majority of ALB in Eastern Indian Ocean were caught in mature condition with the average length $92 \mathrm{cmFL}$. The highest distribution of mature ALB was found at $\left(30-35^{\circ} \mathrm{S}\right.$ and $\left.80-95^{\circ} \mathrm{E}\right)$ and $(10$ $15^{\circ} \mathrm{S}$ and $\left.120-125^{\circ} \mathrm{E}\right)$. The length-weight relationship of ALB were negative allometric, where the growth in length is faster than the growth in weight. The majority of ALB were caught at depth of $156 \mathrm{~m}$ with average temperature $18^{\circ} \mathrm{C}$. The intensity of the feeding habit ALB conducted between 07.45 am-
$17.59 \mathrm{pm}$ with the highest frequency at 10.00-11.00 am. This study suggests that the best time to cacth ALB in June-July at the depth hook of $156 \mathrm{~m}$. The catch of ALB recommended during the day at 07.45 am-17.59 pm.

\section{Acknowledgements}

I would like to thank to observers of Research Institute for Tuna Fisheries (RITF) Benoa Bali, $\mathrm{Mr}$ Abram Barata, Mr Andi Bachtiar, Mr Yusuf Affandi, 
Mr. Dian Novianto, , Mr. Ashadi, Mr. Hasan Syaiful Rizal, Mr. Adi Subagio. We also thanks to Director of RITF, Budi Nugraha S.Pi, M.Si. for valuable input and comments.

\section{References}

Barata, A., Novianto, D. \& Bahtiar, A. 2011a. The distribution of tunas based on temperature and depth in Indian Ocean. IImu Kelautan. 16(3):165-170 doi: 10.14710/ik.ijms.16.3. 165-170

Barata, A., Bahtiar, A. \& Hartaty, H. 2011b. The Effect of Different Bait and Setting Time of Tuna Longline to The Catch of Tuna in Indian Ocean. Indo. Fish. Res. J. Res. Centre Fish. Managem. Con. Jakarta. 17(2):133-138

Chavance, P. 2005. Depth, Temperature and Capture Time of Longline Targeted Fish in New Caledonia Results of a One Year Study. Paper for 1st Meeting of the Scientific Committee of the Western and Central Pacific Fisheries Commission. WCPFC-SC1, Noumea, New Caledonia 8-19 August 2005.

Chen I.C., Lee P.F. \& Tzeng, N.W. 2005. Distribution of albacore (Thunnus alalunga) in the Indian Ocean and Its Relation to Environmental Factor. Fish Oceanography. Vol. 1 (14):71-80 doi: 10.1111/j.1365-2419.2004.00322.x

De Metrio, G. \& Megalofonou, P. 1998. Catch and Size Distribution, Growth and Sex Ratio of Swordfish (Xiphias gladius L.) in Gulf of Taranto. FAO Fisheries Report, No. 394p.

DGCF. 2012. Capture Fisheries Statistic 2011. Directorate General of Capture Fisheries, Ministry of Marine Affairs and Fisheries, Jakarta. 190p

Effendie, MI, 2002. Fisheries Biology. Pustaka Nusantara Foundation.Yogyakarta

Farley, J.H., Ashley, J.W., Cambell, R.D., Naomi, P.C.J., Paige, E., Simon, D.H. \& Simon, J.N. 2012. Population Biology of Albacore Tuna in the Australian Region. FRDC Project;no. 2009/012 Final Report, 124 p.

Gunarso, W. 1998. Fish Behaviuor and Fishing Rod. Lecture Dictates. Fish Behaviour Laboratory, Fisheries and Marine Science Faculty, Bogor Agricultural University. Bogor. 119p
IOTC. 2007. Executive summaries of the status of the major Indian Ocean tunas and billfish (albacore, bigeye, yellowfin, skipjack, and swordfish). Executive Summary of The Status of The Albacore Tuna Resource. IOTC-2007SC-03 [E], pp.46

Irianto, H.E., Wudianto, Satria, F. \& Nugraha, B., 2013. Tropical tuna fisheries in the Indian Ocean of Indonesia. Scientific Committee Meeting, IOTC-2013-WPTT15-20 14p

ISSF. 2014. Status of the world fisheries for tuna: management of tuna stocks and fisheries. 2014. ISSF Technical Report 2014-05. International Seafood Sustainability Foundation. Washington, D.C. USA

Lee, P.F., Chen, I.C. \& Tseng, W.N. 1999. Distribution pattern of three dominant tuna species in the Indian Ocean. Department of Zoology National Taiwan University.

Lehodey, P. 2001. The pelagic ecosystem of the tropical Pacific Ocean: dynamic spatial modelling and biological consequences of ENSO. Progress Oceanogr. 49:439-468 doi: 10.1016/S0079-6611(01)00035-0

Levesque, J.C. 2010. Evolving fisheries: today's bycatch is tomorrow target catch-escolar (Lepidocybium flavobrunneum) catch in the U.S pelagic longline fishery. Open Fish. Sci. J. 3:30-41. doi: 10.2174/1874401X01003010 030

Masuma, S., Kawamura, G., Tezuka, N., Koiso, M., \& Namba, K., 2001. Retinomotor Responses of Juvenile Bluefin Tuna Thunnus thynnus. Fish. Sci, 67:228-231. doi: 10.1046/j.14442906.2001.00244.x

Musyl, M.K., Brill, R.W., Boggs, C.H., Curran, D.S., Kazama, T.K. \& Seki, M.P., 2003. Vertical Movements of Bigeye Tuna (Thunnus obesus) Associated With Islands, Bouys And Seamounts Near The Main Hawaiian Islands from archival tagging data. Fish. Oceanograp. 12:152-169. doi: 10.1046/j.1365-2419.200 3.00229.x

Nishida, T. \& Tanaka, M. 2008. General Review of Indian Ocean Albacore (Thunnus alalunga). IOTC-2008-WPTe-INF03.8 pp.

Nugraha, B. \& Triharyuni, S. 2009. The effect of temperature and hook depth of tuna longline to catch of tuna in Indian Ocean. Indon. Fish. Res. J. Res. Centre Fish. Managem. Con. 
Indonesian Fisheries and Marine Affairs. 3 (15):239-247

Proctor, C., Andamari, R., Retnowati, D., Prisantoso, B.I., Poisson, F., Herrera, M. \& Fujiwara, S. 2007. The catch of SBT by the Indonesian longline fishery operating out of Benoa, Bali in 2006, CCSBT $8^{\text {th }}$ Meeting of the Stock Assessment Group and $12^{\text {th }}$ Meeting of the Extended Scientific Committee, Hobart, Australia, 4-8 September 2007 and 10-14 September 2007.

Research Institute for Tuna Fisheries (RITF). 2013. Research On Swimming Layer And Feeding Periodicity Of Tuna In Indian Ocean. Annual Report 2013, 131p

Rochman, F., Widodo, S.P. \& Irwan, J. 2016. The Influence Of Swimming Layer And Sub-Surface Oceanographic Variables On Catch Of Albacore ( $T$. alalunga) in Eastern Indian Ocean. Indo. Fish. Res. J. Agency for Marine and Fisheries Research \& Development. Ministry of Marine and Fisheries. 2(2):69-76. doi: 10.1016/ j.dsr2.2014.03.010i.
Setyadji, B.D., Novianto, B., Nugraha \& Sadiyah, L. 2012. Catch and size distribution of albacore (Thunnus alalunga) in the Eastern Indian Ocean. IOTC-2012-WPTmT04-13.p 11

Ueyanagi, S. 1969. Observations on the distribution of tuna larva in the Indo-Pacific Ocean with emphasis on the delineation of spawning areas of albacore (Thunnus alalunga). Bull. Far Seas Fish. Res. Lab. 2:177-219

Wu, C.L. \& Kuo, C.L. 1993. Maturity and fecundity of albacore, (Thunnus alalunga) (Bonnaterre), from the Indian Ocean. J. Fish. Soc. Taiwan, 20:135-151

Zhu, G., Xu, L., Zhou, Y. \& Dai, X. 2008. Lengthfrequency composition and weight- length relationship for bigeye tuna, yellowfin tuna and albacore (Perciformes: Scombrinae) in the Atlantic, Indian, and Eastern Pacific Ocean. Acta Ichthyologica et piscatorial. 2(38):157161 